\title{
Manajemen Anestesi untuk Seksio Sesarea pada Pasien Pre Eklampsia Berat yang Terinfeksi Covid-19
}

\author{
RTH Supraptomo \\ Departemen Anestesiologi \& Terapi Intensif Fakultas Kedokteran Universitas Sebelas Maret-RSUD Dr. Moewardi \\ Surakarta
}

\begin{abstract}
Abstrak
Komplikasi hipertensi tercatat 6-8\% pada kehamilan dan menjadi kontributor yang signifikan morbiditas dan mortalitas maternal dan perinatal. Di Amerika Serikat, preeklamsia menjadi satu dari tiga besar penyebab utama kematian ibu hamil. Penanganan yang tidak sesuai dengan standar, sering menjadi penyebab utama yang menyebabkan peningkatan morbiditas dan mortalitas pada ibu hamil. Seorang wanita 30 tahun early warning score (EWS) score 6 dengan preeklampsia pada sekundigravida (G2P1A0) hamil preterm belum dalam persalinan, riwayat seksio sesarea $1 \mathrm{x}$ pro seksio sesarea transperitoneal emergensi dengan status fisik ASA IIE, direncanakan dilakukan anestesi dengan teknik regional anestesi sub-arachnoid block (SAB). Manajemen anestesi pada kehamilan dengan pre-eklampsia meliputi preoperatif, intraoperatif dan postoperatif. Pada masa pandemi COVID-19 dibutuhkan penggunaan alat pelindung diri (APD) yang memadai selama tindakan perioperatif. Perhatian khusus pada anestesi pasien terinfeksi COVID-19 meliputi penggunaan ruangan bertekanan negatif, meminimalisir instrumentasi jalan nafas, serta penggunaan APD level 3.
\end{abstract}

Kata kunci: covid-19, pre-eklampsia, anestesia regional, seksio sesarea

\section{Anesthesia Management for Caesarean Section in Severe Pre-Eclampsia Patients Infected with Covid-19}

\begin{abstract}
Hypertensive complications account for $6-8 \%$ of pregnancy and are a significant contributor to maternal and perinatal morbidity and mortality. In the United States, preeclampsia is one of the top three causes of death for pregnant women. Handling that is not in accordance with standards is often the main cause that causes increased morbidity and mortality in pregnant women. A 30-year-old woman with early warning score (EWS) score 6 with preeclampsia in secondary pregnancy (G2P1A0) who is preterm pregnant yet in labor, a history of cesarean section 1x pro-cesarean section emergency transperitoneal with ASA IIE physical status, planning to perform anesthesia with regional anesthesia technique. sub-arachnoid block (SAB). Anesthesia management in pre-eclampsia pregnancy includes preoperative, intraoperative and postoperative. During the COVID-19 pandemic, adequate personal protective equipment (PPE) is required during perioperative measures. Special attention to anesthesia for patients infected with COVID-19 includes the use of negative pressure rooms, minimizing airway instrumentation, and the use of level 3 PPE.
\end{abstract}

Key words: covid-19, pre-eclampsia, regional anesthesia, caesarean section 


\section{Pendahuluan}

Komplikasi hipertensi tercatat $6-8 \%$ pada kehamilan dan menjadi kontributor yang signifikan morbiditas dan mortalitas maternal dan perinatal. Di Amerika Serikat preeklamsia menjadi satu dari tiga besar penyebab utama kematian ibu hamil. Penanganan yang tidak sesuai dengan standard sering menjadi penyebab utama yang menyebabkan peningkatan morbiditas dan mortalitas pada ibu hamil. ${ }^{1}$ Seperti kita ketahui bahwa pre-eklamsia adalah terjadinya trias pre-eklamsia (hipertensi, hipoalbuminemia, dan edema) yang mendadak pada kehamilan setelah 20 minggu, sedangkan eklamsia adalah pre-eklamsia berat yang diikuti dengan kejang di mana sebelumnya tidak terjadi gangguan neurologis. Terapi utama yang harus dilakukan adalah melakukan terminasi kehamilan tersebut, hal ini akan memberikan pilihan yang sulit bagi dokter spesialis anestesi khususnya, oleh karena itu pemahaman fisiopatologis harus diketahui secara cermat dan teliti. ${ }^{1-3}$ Dengan memahami patofisiologi dari pre-eklamsia ini sangat berkaitan sekali dengan kepentingan bagi ahli anestesi. Yang mana menjadi modal awal sebelum memilih apakah akan melakukan dengan anestesi regional atau anestesi umum untuk melakukan terminasi kehamilan pada pasien dengan preeklamsia berat. Kalaupun dengan regional anestesi maka apakah menggunakan spinal anestesi ataukah dengan epidural anestesi. Hal ini menjadi pilihan untuk kepentingan keselamatan bagi janin maupun ibu. ${ }^{4}$

Pre-eklamsia merupakan komplikasi kehamilan yang dapat menjadi kegawatan pada waktu timbul gejala-gejala neurologis, seperti nyeri kepala yang menetap dan berat, kebutaan dan kejang, disertai dengan hipertensi dan proteinuria pada akhir kehamilan, Kejadian yang bisa menjelaskan gejala neurologis pre-eklamsia berat dan eklamsia adalah adanya syndrome encephalopathy posterior yang reversibel pada saat terjadi kenaikan tekanan darah. Kondisi ini terjadi pada pre-eklamsia yang disebabkan oleh gagalnya autoregulasi, bocornya sawar darah otak. ${ }^{3,5,6}$

\section{Kasus}

\section{Anamnesis}

Pada tanggal 8 Mei 2020, datang seorang wanita G2P1A0 usia 30 tahun ke IGD Rumah Sakit dr. Moewardi kiriman dari RSUD Sragen. Selama kehamilan, pasien kontrol rutin di tempat praktek bidan 3 bulan sekali. Sebelum hamil dan selama hamil, pasien mengalami hipertensi namun tidak pernah kejang. Pasien tidak mengeluhkan demam. Tidak ada keluhan batuk, pilek, sesak, maupun nyeri tenggorokan. Pasien memiliki riwayat kontak dengan suami positif covid-19 (konfirmasi swab positif). Saat ini pasien sudah merasakan kencang-kencang teratur pada perutnya, gerakan janin masih dirasakan. Nyeri kepala, nyeri ulu hati, sesak nafas disangkal. Pasien mengaku pernah melakukan seksio sesarea pada bulan Desember tahun 2015. Pasien menyangkal adanya riwayat penyakit asma, alergi, diabetes ataupun hipertensi. Pasien menyangkal adanya konsumsi obat selain multivitamin selama periode kehamilan kini. Pasien mengaku riwayat makan dan minum terakhir adalah 6 jam sebelum datang ke IGD Rumah Sakit dr. Moewardi.

\section{Pemeriksaan Fisik}

Kondisi pasien sadar penuh, GCS E4V5M6. Pasien memiliki tekanan darah 140/90 $\mathrm{mmHg}$, nadi $113 \mathrm{x} /$ menit, laju respirasi $20 \mathrm{x} / \mathrm{menit}$, suhu $36,6^{\circ} \mathrm{C}$, saturasi oksigen $99 \%$ dengan nasal kanul 2 lpm. Pasien memiliki berat badan $65 \mathrm{~kg}$ dan tinggi badan $160 \mathrm{~cm}$. Airway pasien clear dengan kemampuan buka mulut $3 \mathrm{~cm}$, TMD 6 $\mathrm{cm}$, gerak leher bebas, mallampati II, trakea di tengah, serta tidak ditemukan adanya gigi palsu dan gigi ompong. Pada pemeriksaan mata, kedua konjungtiva tidak anemis dan refleks cahaya kedua mata positif. Pada pemeriksaan thorax ditemukan bentuk normochest, simetris, pengembangan dada kanan sama dengan pengembangan dada kiri, tidak ditemukan adanya retraksi dan penggunaan otot bantu nafas, suara perkusi sonor dan suara dasar vesikuler pada kedua lapang paru, tidak ditemukan adanya suara tambahan. Pada pemeriksaan jantung ditemukan bunyi jantung 1 dan 2 tunggal, irama reguler, tidak ditemukan adanya murmur. Pada pemeriksaan abdomen didapatkan distensi gravidarum, gerak 
peristaltik dalam batas normal, bising usus dalam batas normal, tidak ada nyeri tekan abdomen, gravid, denyut jantung janin (DJJ) 142x/menit regular, kepala janin belum masuk panggul. Pada pemeriksaan ekstremitas, akral dirasakan hangat, oedema di seluruh ekstremitas.

\section{Pemeriksaan Penunjang}

Untuk mengetahui kondisi hemodinamik dan status elektrolit pasien sebelum tindakan operasi, dilakukan pemeriksaan laboratorium darah pada tanggal 8 Mei 2020. Hasil pemeriksaan laboratorium darah dapat dilihat pada tabel 1 .

Tabel 1. Hasil Pemeriksaan Laboratorium Darah tanggal 8 Mei 2020

\begin{tabular}{|c|c|c|c|}
\hline Pemeriksaan & Hasil & Satuan & Rujukan \\
\hline $\mathrm{Hb}$ & 12,8 & $\mathrm{~g} / \mathrm{dl}$ & $12,0-15,6$ \\
\hline HCT & 38 & $\%$ & $33-45$ \\
\hline $\mathrm{RBC}$ & 4,34 & $10^{6} / \mu \mathrm{l}$ & $4,10-5,10$ \\
\hline WBC & 9,1 & $10^{3} / \mu \mathrm{l}$ & $4,5-11$ \\
\hline AT & 238 & $\mathrm{mg} / \mathrm{dL}$ & $150-450$ \\
\hline GDS & 65 & $\%$ & $60-140$ \\
\hline Netrofil & 76,60 & $\%$ & \\
\hline Limfosit & 10,30 & & $20,0-40,0$ \\
\hline $\begin{array}{l}\text { Golongan } \\
\text { darah }\end{array}$ & $\mathrm{O}$ & $\mathrm{U} / \mathrm{L}$ & \\
\hline SGOT & 34 & $\mathrm{U} / \mathrm{L}$ & $<23$ \\
\hline SGPT & 10 & detik & $<21$ \\
\hline PT & 12,2 & detik & $10,0-15,0$ \\
\hline APTT & 31,7 & & $20,0-40,0$ \\
\hline INR & 0,920 & & \\
\hline Ureum & 20 & $\mathrm{mg} / \mathrm{dL}$ & $<50$ \\
\hline Kreatinin & 0,6 & $\mathrm{mg} / \mathrm{dL}$ & $0,5-1,1$ \\
\hline Albumin & 3,4 & $\mathrm{~g} / \mathrm{L}$ & \\
\hline $\mathrm{Na}$ & 134 & $\mathrm{mmol} / \mathrm{L}$ & $132-145$ \\
\hline $\mathrm{K}$ & 3,4 & $\mathrm{mmol} / \mathrm{L}$ & $3,3-5,1$ \\
\hline $\mathrm{Ca}$ & 1,11 & $\mathrm{mmol} / \mathrm{L}$ & \\
\hline HbsAg & Nonreaktif & & Nonreaktif \\
\hline Proteinuria & +++ & & \\
\hline
\end{tabular}

Hasil laboratorium darah dalam batas normal. Oleh karena pasien memiliki riwayat kontak dengan pasien COVID-19. Dokter anestesi melakukan assessment Early Warning Score (EWS) COVID-19. Total score
Tabel 2. EWS Score COVID-19 tanggal 8 Mei 2020

\begin{tabular}{ll}
\hline Paramater & Skor \\
\hline Pneumonia & 0 \\
Riwayat kontak & 5 \\
Laki-laki & 0 \\
Demam & 0 \\
Respiratory symptoms & 0 \\
Usia 30 th & 0 \\
N/L $(7,6)$ & 1 \\
Total score & 6 \\
\hline
\end{tabular}

EWS COVID-19 pada pasien ini adalah 6 .

\section{Pengelolaan Anestesi}

Dokter anestesi juga berkolaborasi dengan dokter paru untuk persiapan kondisi pasien sebelum operasi. Dokter paru memberikan diagnosa Pasien Dalam Pengawasan (PDP) covid 19 dan preeklampsia berat (PEB). Diagnosa ini ditegakkan berdasarkan Rapid test IgM CoV-19 positif dan Swab test dan polymerase chain reaction (PCR) positif $\mathrm{CoV}-19$. Adapun sebelum operasi berlangsung, dokter kandungan memberikan tambahan terapi nifedipin $10 \mathrm{mg}$. Berdasarkan kondisi pasien, diagnosis anestesi sebagai berikut: wanita 33 tahun dengan pre eklampsia pada sekundigravida (G2P1A0) hamil preterm belum dalam persalinan, riwayat seksio sesarea $1 \mathrm{x}$ pro seksio sesarea transperitoneal emergensi dengan status fisik ASA IIE, plan regional anestesi subarachnoid block. Saran tindakan dari anestesi adalah informed consent risiko tinggi, pasang jalur intravena, puasa diteruskan, post operasi rawat di ICU.

Selanjutnya pasien dilakukan persiapan operasi antara lain, Keluarga dan pasien diberi penjelasan tentang rencana yang akan dilakukan, prosedur tindakan anestesi dan operasi dan kemungkinan hal-hal yang bisa terjadi selama tindakan, stop makan dan minum, petugas operasi memakai alat pelindung diri (APD) level III yang terdiri dari handscoon steril biasa, sepatu boot, cover all, respirator N95 mask, medical mask, eye protection/kacamata google, face shield, apron kedap air, dan handscoon steril panjang, 
pemakaian dilakukan sesuai standard operating procedure (SOP), pemasangan infus RL, persiapan obat dan alat, komunikasi dengan teman sejawat obsgin tentang tindakan seksio sesarea emergensi transperitoneal yang akan dilakukan.

Pada tanggal 9 Mei 2020, pasien telah dalam kondisi stabil sehingga tindakan operasi dapat berlangsung sesuai rencana. Pembiusan dimulai pukul 07.00 berlangsung 60 menit, sampai pukul 08.00. Tindakan bedah dilakukan mulai pukul 07.05-07.55 WIB. Pasien masuk kamar sudah terpasang jalur intravena no. 18G dengan cairan RL. Di kamar operasi dipasang monitor EKG, pulse oxymetry dan tekanan darah. Tercatat tekanan darah 150/100 $\mathrm{mmHg}$, nadi 98x/menit, $\mathrm{SaO}_{2} 100 \%$. Premedikasi diberikan metoclopramid $10 \mathrm{mg}$ dan ranitidin 1 ampul. Setelah pasien telah terbius, dilakukan tindakan seksio sesarea transperitoneal dengan posisi supinasi pada pasien. Durante operasi diberikan $\mathrm{O}_{2} 3 \mathrm{lpm}$ dengan nasal kanul dan infus ringer laktat. Selama operasi, diberikan juga oksitosin 10 IU dan paracetamol 1 gr per 8 jam. Kondisi pasien saat rumatan anestesi adalah sebagai berikut: 1) suara nafas vesikuler, nafas terkontrol, 2) perdarahan $\pm 250 \mathrm{cc}, 3$ ) pupil isokor, 4) kateter terpasang, urin $100 \mathrm{cc}, 5)$ bising usus (-), 6) tulang intak. Teknik anestesi dengan regional anestesi subarachnoid block, puncture L4-5, jarum spinal ukuran 26G, menggunakan agen SAB bupivacain $0,5 \% 12,5 \mathrm{mg}$ dengan adjuvan fentanyl $25 \mathrm{mcg}$. Pemeliharaan anestesi dengan $\mathrm{O}_{2}$ dan diberikan sedasi dengan midazolam $3 \mathrm{mg}$ setelah bayi lahir.

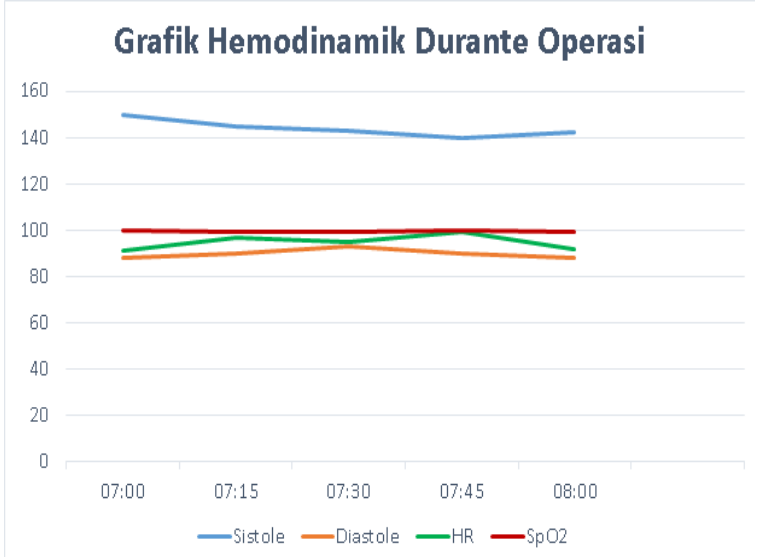

Grafik 1. Hemodinamik Durante Operasi
Selama operasi perdarahan $\pm 300 \mathrm{cc}$, urin output $\pm 100 \mathrm{cc}$. Durante operasi, hemodinamik stabil: tekanan darah sistole $120-130 \mathrm{mmHg}$ dan diastole 80-90 $\mathrm{mmHg}$, nadi $80-90 \mathrm{x} / \mathrm{menit}$, saturasi $\mathrm{O}_{2}$ 99-100\%. Bayi lahir perempuan, APGAR score 7-8-9. Setelah bayi lahir, diberikan oksitosin drip $10 \mathrm{IU}$ iv dan methergin $0,2 \mathrm{mg}$ sebagai uterotonika.

\section{Pengelolaan Pascabedah}

Setelah operasi, pasien dirawat di High Care Unit (HCU) isolasi untuk mendapat perawatan lebih lanjut. Keadaan umum pasien baik, kesadaran composmentis, tekanan darah 140/80 $\mathrm{mmHg}$, nadi $90 \mathrm{x} /$ menit, frekuensi napas $20 \mathrm{x} /$ menit. Tatalaksana post operasi meliputi 1) pengawasan kondisi umum, tanda vital dan tanda perdarahan, 2) puasa hingga bising usus (+), 3) fentanyl 0.5 $\mathrm{mcg} / \mathrm{kgbb} / \mathrm{jam}, 150 \mathrm{mcg}$ dalam $500 \mathrm{cc}$ habis dalam 3 jam. 4) paracetamol $1 \mathrm{gr} / 8 \mathrm{jam}, 5$ ) Oksigen $3 \mathrm{lpm}$, intravenous fluid drops (IVFD) RL 12 tetes per menit, inj. Ketorolak $30 \mathrm{mg} / 8$ jam, vit C 2x50 mg.

\section{Pembahasan}

\section{Patogenesis Preeklampsia}

Preeklamsia merupakan kelainan sistemik yang hanya terjadi dengan adanya jaringan plasenta. Meskipun demikian mekanisme patogenesisnya belum diketahui dengan pasti. Pada wanita dengan preeklamsia,terjadikegagalaninvasitrophoblastic ke dalam deciduo-myometrial junction yang menyebabkan resistensi tinggi, low-flow sirkulasi uteroplasenta dan berakibat hipoksia dan iskemia plasenta. Faktor genetik pada preeklamsia adalah kompleks, bersifat resesif. Faktor-faktor tersebut antara lain: angiotensinogen gen T235 berhubungan dengan preeklamsia, bersifat homosigot, angiotensin II Tipe I reseptor, faktor V Leiden, dan tumor necrosis faktor-alpha. ${ }^{1,9,10}$

Kerusakan dan disfungsi endotel pembuluh darah merupakan gambaran patologi pada preeklamsia dan terjadi pada pembuluh darah desidua plasenta dan mikrovaskular ginjal. Kerusakan endotel menyebabkan spasme arteriolar pada hati, miokard dan sirkulasi otak. Pada preeklamsi terjadi kegagalan invasi trophoblast ke dalam uteroplacental vascular yang menyebabkan 
meningkatnya radikal bebas dan Lipid peroxide oleh jaringan Limfoid decidual. ${ }^{11}$ Radikal bebas ini yang akan merusak endotel pembuluh darah. Lipid peroxida mengaktifkan cyclo oxygenase dan menghambat sintesis PGI2 dan pelepasan nitric oxide yang akan mengakibatkan produksi vasokontriktor thromboxane (TXA2) meningkat dan meningkatkan kadar plasma vasokontriktor endothelin. Sebuah penelitian menjelaskan preeklamsia sebagai trophoblast-dependent process, yang diperantarai oleh disfungsi platelet dan dihambat oleh anti-platelet agent. Disfungsi platelet ini dijembatani oleh rusaknya endotel pembuluh darah. Penurunan PGI2 dan nitric oxide akan mengaktifasi permukaan pembuluh darah yang dimediatori platelet dan terjadi adhesi pada arteri. Adhesi platelet akan melepaskan granula-granula yang meliputi TXA2 $\neg$ dan serotonim (5-hydroxytryptamine/5-HT) yang meningkatkan agregasi platelet lebih lanjut. ${ }^{11,12}$

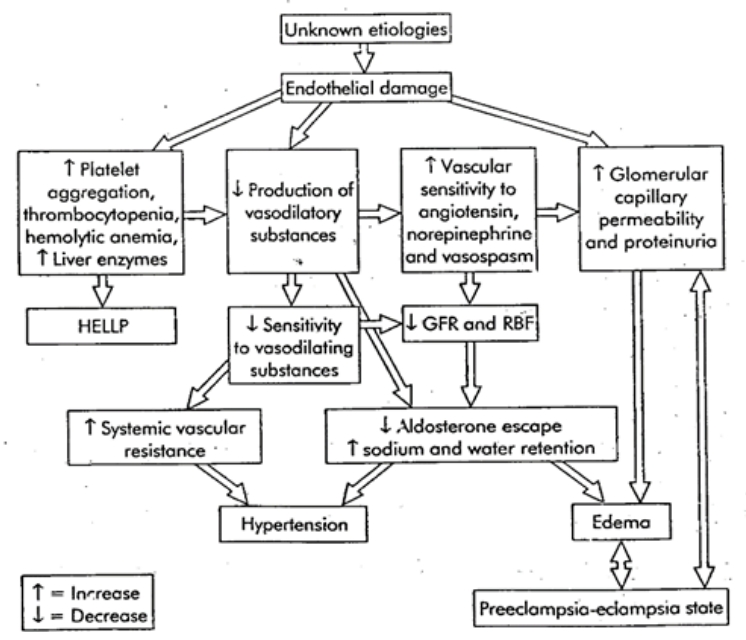

Gambar 2. Patogenesis Preeklampsia

Kalsium intraseluler merupakan faktor penting terhadap tonus dan kontraktilitas otot pembuluh darah. Peningkatan lipid peroxidasi sel membran akan meningkatkan permiabilitas kalsium yang menyebabkan peningkatan kalsium dalam sitoplasma yang akan diperberat oleh angiotensin II. Abnormalitas koagulasi terlihat pada penderita preeklamsia yang mungkin akibat dari aktifasi endothel oleh vasculer endothelial growth factor (VEGF). ${ }^{13-15}$
Manajemen Anestesi pada Seksio Sesarea

Emergency dengan COVID

Wuhan, kota di bagian Cina tengah, telah melaporkan wabah pneumonia atipikal yang disebabkan oleh coronavirus novel 2019 pada akhir 2019. Coronavirus ini secara pada awalnya dinamai sindrom pernafasan akut coronavirus 2 (SARS-CoV2). Ada banyak wanita hamil yang menderita penyakit coronavirus 2019 (COVID-19), yang tidak diragukan lagi bisa jadi ancaman bagikesehatan ibu dan bayi. SARS-CoV-2 dapat ditularkan melalui droplet dari pernapasan normal, batuk, dan bersin, dan dengan aerosol atau cairan dari sekresi atau pembuangan manusia.

Penggunaan APD level III diimplementasikan di ruang operasi, termasuk handwashing clothes, masker standar medis (N95) dan disposable surgical cap, kacamata googles (atau tutup kepala tekanan positif), pakaian pelindung sekali pakai, handscoon sekali pakai, dan shoe covers sekali pakai.MaskerN95terbuktisecaraefektifmencegah aerosol atau cairan sekresi secara efektif. ${ }^{16-18}$ Anestesi spinal single shot maupun combined epidural dengan prosedur yang sesuai selama seksio sesarea emergensi pada pasien COVID-19 dilaporkan aman bagi pasien dengan infeksi aktif COVID 19 gejala ringan. Bayi yang dilahirkan bisa bebas dari infeksi. Selain itu, anestesi spinal dapat ditoleransi dengan baik. Denyut jantung, tekanan darah, dan saturasi oksigen tetap stabil setelah operasi. Profilaksis anti-emetik diberikan untuk mengurangi risiko muntah dan viral spread. Pemilihan ropivacaine maupun bupivacaine juga tidak ada efek samping selama periode intraoperatif pada kasus COVID 19.

Meskipun ada perubahan pada angka leukosit setelah operasi, yang lebih utama adalah tidak ada perburukan pada outcome pasien COVID 19..$^{16-18}$ Risiko penularan vertikal SARS-CoV-2 rendah, karena pada sebuah studi kasus, mereka tidak mendeteksi virus pada bayi maupun produk konsepsi lainnya seperti plasenta. Studi sebelumnya menunjukkan bahwa influenza, SARS, dan MERS, dapat mengakibatkan abortus pada wanita hamil, jika dibandingkan dengan individu yang tidak hamil. Infeksi virus dari kasus-kasus yang disebutkan di atas selama 
kehamilan juga diduga menjadi penyebab outcome neonatal yang buruk. Karena respon imun terhadap infeksi SARS-CoV-2, ada kemungkinan bahwa ibu menghasilkan antibodi penawar yang cukup sehingga tidak terjadi perburukan pada bayi yang dikandungnya., ${ }^{4}$

\section{Manajemen Anestesi Preoperatif}

Penanganan pasien pre-eklampsia idealnya secara multidisiplin. Ahli anestesi dapat berperan dalam penanganan intensif dan anestesi pada pasien yang akan dilakukan tindakan pembedahan. Penanganan sebelum dilakukan operasi meliputi kontrol kejang, manajemen kardiovaskuler dan respirasi, fungsi ginjal, hepar dan koagulasi. Kontrol kejang dapat dilakukan dengan pemberian agen anti konvulsi atau dengan preparat magnesium sulfat. Pemberian diazepam sangat terbatas dan kurang disukai karena efek depresi pada janin, sedangkan fenitoin dapat digunakan dengan dosis $10 \mathrm{mg} / \mathrm{kgBB}$ bolus dalam $100 \mathrm{cc}$ salin diberikan $50 \mathrm{mg} / \mathrm{menit}$ karena efek depresinya kecil pada janin. Magnesium bersifat vasodilator serebral yang kuat, dan memberikan kontrol kejang yang lebih baik daripada pemberian diazepam, dan difenil hidantoin. Dosisnya 40-80 $\mathrm{mg} / \mathrm{kgBB}$. Cara kerjanya berdasar blokade influx kalsium pada saluran subtipe glutamat $N$-metylD-aspartat (NMDA). ${ }^{10,11}$

Penanganan hipertensi dianjurkan untuk diturunkan secara gradual karena efek ke perfusi fetus dan penurunan tekanan darah yang mendadak dapat menyebabkan resiko jejas pada serebral. Obat anti hipertensi yang sering digunakan antara lain nifedipin $10 \mathrm{mg}$ tiap 20 menit sublingual. Obat ini dapat memperbaiki fungsi ginjal dengan meningkatkan aliran darah ginjal. Dihidralazin $5 \mathrm{mg}$ intravena diikuti infus 5-20 mg/jam dapat digunakan tetapi onsetnya lambat sehingga interval yang disarankan untuk pemberian berikutnya adalah 20 menit. Pembedahan pada kasus pre-eklampsia/eklampsia merupakan pembedahan darurat, sehingga waktu yang diperlukan untuk melakukan penilaian preoperatif sangat sedikit. Meskipun waktu yang tersedia sangat sedikit, tetapi harus dilakukan anamnesis, pemeriksaan fisik dan penunjang dengan seksama. Penilaian preoperatif pada pasien pre-eklampsia/eklampsia bertujuan untuk: menilai status kejang dan fungsi neurologis, terutama peningkatan tekanan intrakranial, pemeliharaan kebutuhan cairan/balance cairan, kontrol tekanan darah, oksigenasi yang cukup dan uji laboratorium meliputi darah rutin, faktor koagulasi dan fungsi hepar. ${ }^{10-13}$

Pada pasien ini, dari anamnesis ditemukan bahwa pasien tidak pernah menderita hipertensi dan tidak pernah kejang sebelumnya. Tidak ada pusing, mual, muntah atau gangguan neurologis lainnya. Pada pemeriksaan fisik, didapatkan tekanan darah 150/100 mmHg, tidak ada odem tungkai, tidak ada tanda-tanda dehidrasi dan pemeriksaan fisik lainnya masih dalam batas normal. Pada pemeriksaan laboratorium, ditemukan protein urine +3 , fungsi koagulasi normal, fungsi hepar normal dan yang lainnya masih dalam batas normal. Untuk menjaga kondisi pasien stabil, di kamar bersalin telah diberikan $\mathrm{MgSO}_{4}$ loading dose $6 \mathrm{mg}$ (untuk mencegah kejang), nifedipin sublingual $10 \mathrm{mg}$ (untuk mengontrol hipertensi), oksigenasi 2 1/menit dengan nasal kanul dan infus RL untuk kebutuhan cairan dan terpasang kateter urin untuk menilai kecukupan cairan. Pasien dengan kehamilan dianggap memiliki lambung penuh, untuk itu dilakukan persiapan dengan pemberian anti muntah. Pada pasien ini diberikan prokinetik golongan metoklopramid $10 \mathrm{mg}$ iv dan AH2 blocker ranitidin 50mg.

\section{Manajemen Anestesi Durante Operasi}

Banyak para ahli menganggap bahwa tehnik anestesi neuraxial merupakan pilihan terbaik untuk menangani pasien pre eklampsia jika tidak ada kontra indikasi. Pada tehnik subarachnoid block, selain memberikan anestesia yang baik, juga menekan sekresi epinefrin dan norepinefrin, dimana keduanya dapat memperburuk aliran darah ke uterus dan ginjal. Keuntungan lain yang didapat adalah perfusi perifer yang lebih baik, aliran darah uteroplasenter meningkat, pengaruh obat anestesi pada bayi minimal, tidak memanipulasi jalan nafas ibu hamil. ${ }^{14,15}$ Pemantauan hemodinamik sangat penting pada pasien preeklampsia/eklampsia. Tekanan darah harus stabil, karena hipertensi sistemik dan pulmonal akan meningkatkan kejadian stroke dan 
odem pulmo. Pemasangan alat-alat monitoring sangat penting untuk mengetahui perubahan hemodinamik.

Pada pasien ini, monitoring hemodinamik menggunakan monitor EKG, pulse oxymetry, tekanan darah dan nadi. Selama operasi hemodinamik stabil dengan tekanan darah sistolik $120-130 \mathrm{mmHg}$ dan diastolik $80-90 \mathrm{mmHg}$, nadi $80-90 \mathrm{x} /$ menit. Untuk mencegah hipotensi yang berkepanjangan digunakan efedrine intravena. Selama operasi berlangsung, kebutuhan cairan harus diperhatikan. Pada pasien dengan penyakit yang berat, volume cairan intravaskuler berkurang, tetapi jumlah total cairan tubuh meningkat, sehingga harus hati-hati dalam pemberian cairan karena dapat timbul odem pulmo. Monitoring kecukupan cairan harus dilakukan selama operasi. Pada kasus ini cairan yang digunakan adalah kristaloid dengan restriksi $80 \mathrm{cc} / \mathrm{jam}$ untuk mencegah overload cairan. Pemantauan kecukupan cairan dengan memantau cairan output $0,5-1 \quad \mathrm{cc} / \mathrm{kgBB} / \mathrm{jam}$. Selama operasi berlangsung \pm 60 menit, urin output sebanyak \pm 100 cc dengan berat badan pasien $60 \mathrm{~kg}$. Perdarahan yang terjadi selama operasi \pm 300 cc. Jumlah perdarahan ini tidak melebihi ABL (Allowable blood loss $1.105 \mathrm{cc}$ ) pasien, sehingga tidak perlu transfusi selama operasi.

\section{Perawatan Pasca Operasi}

Penderita eklampsia pasca operasi harus dirawat di HCU agar dapat dilakukan pemantauan yang baik terhadap komplikasi PEB yang mungkin terjadi, perkembangan penyakitnya dan pengobatan sebelum anestesi. Pada prinsipnya, pengelolaan pasca operasi HCU adalah monitoring hemodinamik, mencegah terjadinya kejang dan komplikasi sistem saraf pusat serta optimalisasi fungsi hepatorenal. Pada kasus ini, pasca operasi, pasien di rawat di HCU dalam kondisi sadar penuh, nafas spontan adekuat dan hemodinamik stabil.

\section{Simpulan}

Telah dilaporkan sebuah kasus anestesi pasien pre-eklamsia pada sekundigravida hamil preterm belum dalam persalinan dengan riwayat SC $1 \mathrm{x}$.
Operasi berjalan lancar selama 60 menit. Selama operasi hemodinamik stabil. Anestesi pada wanita hamil dengan eklampsia harus dilakukan dengan hati-hati mulai dari pre-operasi, durante operasi dan post-operasi. Eklamsia yang merupakan penyakit multisistemik memerlukan teknik anestesi yang sesuai dengan kondisi pasien. Perhatian khusus pada anestesi pasien terinfeksi COVID-19 meliputi penggunaan ruangan bertekanan negatif, meminimalisir instrumentasi jalan nafas, serta penggunaan APD level 3.

\section{Daftar Pustaka}

1. Lelia Dildy G, Belfort MA. Complications of Pre-eclampsia. In : Critical Care Obstetrics, Fifth Edition, Blackwell publishing limited, Chapter 34, 2010; 438-53.

2. Rudra P. Recent advances in management of pre-eclampsia. British Journal of Medical Practicioners. 2011; (4)3.

3. David J. Anesthesia for Obstetrics, In: Millers Anesthesia, 6th edition. Elseiver Churchill Livingstone: Philadelphia, 2005; 2329-333.

4. Jeannie M, Tania H. Anesthesia for Obstetrics and Gynecology, In: Clinical Anesthesia Procedures of the Massachusetts General Hospital. 6th edition, Lippincott Williams and Wilkins: Philadelphia; 2002, 501-03.

5. Sibai BM. Diagnosis, Prevention and Management of Eclamsia. The American College of Obstetricians and Gynecologistes, Lippincott Williams and Wilkins. 2005. 402-10.

6. Hladunewich M, Pathophysiology of the clinical manifestations of preeclampsia. In: Depth Review, California. 2007, 544-49.

7. Chaudhary S. Subarachnoid block for caesarian section in severe pre-eclampsia, In: Journal Of Anaesthesiology Clinical Pharmacology, UCMS and GTB Hospital, Delhi India. 2011, 27. 
8. Ezeikel MR, Handbook of Anesthesiology. Current Clinical Strategy Publishing. 2002, 171-72.

9. WHO, Recommendations for prevention and treatment of Pre-eclampsia and Eclampsia, WHO library Cataloguing-in-Publication Data, WHO, 2011, 20 -7

10. Ramanathan S. Recent advances in anesthesia and analgesia. In: Adams AP, ed: Obstetric Anesthesia. Philadelphia: Churchill Livingstone. 1992, 561-69.

11. Xia H, Zhao S, Wu Z, Luo H, Zhou C, Chen $\mathrm{X}$. Emergency caesarean delivery in a patient with confirmed COVID-19 under spinal anaesthesia. Bri J. Anaesth. 2020: 216-18.

12. Zhong Q, Liu YY, Luo Q, Zou YF, Li, H, Jiang H, Zhang J, et al. Spinal anaesthesia for patients with coronavirys disease 2019 and possible transmission rates in anaesthetists: retrospective, single centre, observational cohort study. Br J Anaesth. 2020; 124(6):670 75.

13. Carvalho B. Nonobstetric surgery during pregnancy. IARS Review Course Lectures. 2006
14. Hool A. Anaesthesia in pregnancy for nonobstetric surgery. World Federation of Societies of Anesthesiologist. 2006; 185: 1-9

15. Heazell A, Clift J. Obstetrics for anaesthetists. Cambridge University Press. Cambridge. 2008.

16. Lam CM1, Wong SF, Leung TN, Chow KM, Yu WC, Wong TY, Lai ST, Ho LC. A casecontrolled study comparing clinical course and outcomes of pregnant and nonpregnant women with severe acute respiratory syndrome. BJOG. 2004 Aug;111(8):771-4.

17. Assiri A, Abedi GR, Al Masri M, Bin Saeed A, Gerber SI, Watson JT. Midle east respiratory syndrome coronavirus infection during pregnancy: a report of 5 cases from Saudi Arabia. Clin. Infect. Dis. 2016; 63(7):10 01.

18. Yue L, Han L, Li Q, Zhong M, Wang J, Wan Z, et al. Anaesthesia and infection control in cesarean section of pregnant women with coronavirus disease 2019 (COVID-19). medRxiv [Internet]. 2020 Jan 1;2020.03.23.20040394. 